\title{
Garlic: an alternative in reducing blood glucose on diabetic patients
}

\author{
Putri Dafriani*, Roza Marlinda, Eliza Arman, Meldafia Idaman
}

Department of Public Health, Syedza Saintika’s Health Science Institute, Indonesia

Received: 08 April 2020

Revised: 08 May 2020

Accepted: 11 May 2020

*Correspondence:

Dr. Putri Darfriani,

E-mail: putridafrianiabd@gmail.com

Copyright: (C) the author(s), publisher and licensee Medip Academy. This is an open-access article distributed under the terms of the Creative Commons Attribution Non-Commercial License, which permits unrestricted non-commercial use, distribution, and reproduction in any medium, provided the original work is properly cited.

\section{ABSTRACT}

Background: Diabetes mellitus (DM), a metabolic disorder characterized by an increasing of blood sugar (hyperglycemia). Medication is one of the seven pillars of diabetes managementt. Garlic (Allium sativum), an alternative herb, also has an antidiabetic effect. The purpose of this study was to investigate the effect of garlic on the blood sugar level in type 2 diabetes mellitus.

Methods: This study was a quasi-experimental design with two group post-test design. The participants were DM patients who only take medication without any supplemental herbs. The respondents were divided into two group; intervention group, given antidiabetic drugs and consume garlic 3 pieces of garlic/day for 2 weeks and control group only got antidiabetic drugs. Data were collected by performing blood sugar measurement using glucose-check on all respondents using capillary blood in the fingertips. Second measurement were taken after monitoring the consumption of garlic together with drugs for two weeks. Hypothesis testing used independent T-Test test.

Results: The study result found that the average of blood sugar level after administering the treatment is $240 \mathrm{mg} / \mathrm{dl} \mathrm{in}$ the intervention group, and $284 \mathrm{mg} / \mathrm{dl}$ in control group. It can be concluded that the administration of 3 pieces of garlic combining with antidiabetic drugs for 2 weeks has not been able to reduce blood sugar levels into normal limits.

Conclusions: This combination found to lowering the blood sugar levels in a significant amount compare to only drugs. The length of the therapy could consider as a significant predictor.

Keywords: Blood glucose, Diabetes mellitus, Garlic

\section{INTRODUCTION}

Diabetes mellitus (DM), a metabolic disorder characterized by an increasing of blood sugar (hyperglycemia), is caused by insulin damage. ${ }^{1}$ According to the International Diabetes Federation (2017), the global prevalence of DM is tending to be higher from year to year. Indonesia is one of the six countries with the highest number of DM patients in the world, the number reach 10.3 million.

Persistent hyperglycemia leads to an oxidative stress. Therefore, overcoming of this problem is the key point of diabetes management. Recently, the management of diabetes focused on seven point called seven pillars of diabetes, which are eating a healthy diet, staying fit with exercise, taking the medication, blood sugar levels monitoring, managing stress, discovering how to solveproblem, reducing risk with healthy behaviors and regular medical checkup. As for the medication, patients are given oral hyperglycemic drugs and insulin administration. $^{2}$

Controlling blood sugar levels could be by oral antihyperglycemic drugs and insulin. However, some people struggle with medication adherence due to the number of medications prescribed or the dosing schedule. Besides, the side effects of this medication such as 
hypoglycemia, anemia, impaired absorption of vitamin B, and digestive disorders also should be kept in mind. In the other hand, the use of herbs as natural ingredients to support the therapy should be considered as an alternative. It is because the advantages of natural ingredients are known as an alternative in reducing the side effects of chemical drugs. ${ }^{3}$ Garlic (Allium sativum), often used for maintaining health, is one of the antidiabetic herbs. It can be used as a treatment for diabetes, hypertension, hypercholesterolemia, arthritis rheumatoid, fever or prevention of atherosclerosis, and also inhibitors tumor growth especially by its sulfur content. ${ }^{4}$

The main function of garlic on diabetes is in maintaining blood sugar level. This herb can decrease glucose level. The component such as allyl propyl disulfide and allicin in garlic can be used as antihypertension which reduce the blood pressure, urine protein and plasma creatinine levels. Garlic also protects the kidneys from diabetes nephropathy. ${ }^{5}$ Allicin have function in increasing liver metabolism, insulin secretion and controlling lipid peroxidation. It is also improving the antioxidant status of cells such as superoxide dismutase, catalase and glutathione peroxidase. Thus, garlic is beneficial for the body because it protects cells from the effects of oxidative stress due to hyperglycemia. ${ }^{6}$ Regular consumption of garlic can improve lipid profile, reduce triglycerides, low-density lipoprotein and increase highdensity lipoprotein. The sulfur component in this herb can increase insulin secretion and insulin sensitivity. ${ }^{7}$ Research has found that raw garlic has an antidiabetic effect. In a study where garlic are given as a supplement without the addition of other antidiabetic drugs result a significant decrease in fasting blood glucose levels in 1-2 weeks. ${ }^{8}$ Thus, revealed that garlic (Allium sativum) had a significant effect on increasing glycemic status.

\section{METHODS}

This study was a quasi-experimental design with two group post-test design. Twenty respondents are included with the inclusion criteria are diabetic patients who only take medication without any supplemental herbs, patients who are diagnosed diabetes and have another diseases are excluded.

This study was conducted at the Lumpo Public Health Center, Pesisir Selatan, West Sumatera, Indonesia from March 2019 to April 2019. Ethical clearance was obtained from Medicine Faculty of Andalas University, Padang, Indonesia.

The respondents were divided into two group; intervention group, given antidiabetic drugs and consume garlic 3 pieces of garlic/day for 2 weeks and control group only got antidiabetic drugs. The tools and materials used in this study were glucocheck with the brand ACCU CHEK, lancet, syringe $3 \mathrm{cc}$, lancet pen, cotton, 70\% alcohol, blood glucose test strip and garlic. Data were collected by performing blood sugar measurement using gluco-check on all respondents using capillary blood in the fingertips. Second measurement is taken after monitoring the consumption of garlic together with drugs for two weeks in intervention group and only antidiabetic drugs in control group. Hypothesis testing used independent $\mathrm{T}$-Test test with $\mathrm{p}$ value<0.05. Statistical analysis showed no significant difference between blood sugar levels in the control group and the intervention group after garlic administration ( $p>0.05)$.

\section{RESULTS}

Based on the results of the study in Table 1 showed that the average of blood sugar level in the intervention group is $305.6 \mathrm{mg} / \mathrm{dl}$, standard deviation of 58.392 , and in control group is $343.90 \mathrm{mg} / \mathrm{dl}$, standard deviation of 82.534. This indicated occurrence of hyperglycemia in both groups.

Table 2 presented the average of blood sugar level in the intervention group and control group. After taking 3 pieces of garlic per day together with antidiabetic drugs for 2 weeks in intervention drugs, the mean blood sugar level is $240 \mathrm{mg} / \mathrm{dl}$ (SD 56.19) and in the control group is $284 \mathrm{mg} / \mathrm{dl}$ (SD 58.89).

Table 1: Blood sugar levels of DM patients type 2 before garlic consumption.

\begin{tabular}{|llll|}
\hline Groups & $\mathbf{N}$ & Mean & Standard deviation \\
\hline Control & 10 & 343.9 & 82.534 \\
\hline Intervention & 10 & 305.6 & 58.329 \\
\hline
\end{tabular}

Table 2: Blood sugar levels of DM patients type 2 after consumption of garlic.

\begin{tabular}{|llll|}
\hline Group & N & Mean & Standard deviation \\
\hline Control & 10 & 240 & 56.190 \\
\hline Intervention & 10 & 284 & 58.891 \\
\hline
\end{tabular}

Table 3: Effect of garlic on the blood sugar level in type 2 diabetes mellitus.

\begin{tabular}{|c|c|c|c|c|c|c|c|}
\hline \multirow{3}{*}{ Intervensi dan Kontrol } & \multicolumn{2}{|c|}{$\begin{array}{l}\text { Levene's test for } \\
\text { quality of variance }\end{array}$} & \multicolumn{5}{|c|}{ T-test for equality of means } \\
\hline & \multirow{2}{*}{ F } & \multirow{2}{*}{ Sig } & \multirow{2}{*}{$\mathbf{T}$} & \multirow{2}{*}{ df } & \multirow{2}{*}{$P$ value } & \multicolumn{2}{|c|}{ 95\% CI of the difference } \\
\hline & & & & & & Lower & UppeI \\
\hline Equal variance assumed & 0.207 & 0.654 & 1.717 & 18 & 0.103 & 98.278 & 9.878 \\
\hline $\begin{array}{l}\text { Equal variance not } \\
\text { assumed }\end{array}$ & & & 1.717 & 17.96 & 0.103 & 98.286 & 9.886 \\
\hline
\end{tabular}


Table 3 showed that there is no significant difference between blood sugar levels in the control group and the intervention group after garlic administration ( $\mathrm{p}>0.05)$. It can be concluded that there is no significant effect of giving garlic combined with antidiabetic drugs to the blood sugar levels of type $2 \mathrm{DM}$ patients after 2 weeks of treatment.

\section{DISCUSSION}

Hyperglycemia is one of the signs and symptoms of DM. Based on the respondent's characteristics, half of the respondents $(50 \%)$ are elderly, almost all respondents $(80 \%)$ are female and more than half $(60 \%)$ with high blood pressure. Elder people face some challenges in the physiological change, one of them is insulin resistance. It is caused by changing in the body composition in elderly, where more fat mass than muscle; decreasing physical activity; hormonal factors; diet imbalance, high carbohydrates consumption. The same results were also obtained in DM patients at the Gombok Health Center in Sijunjung District, $50 \%$ of patients were over 45 years old. ${ }^{9}$

Gender also influence the blood sugar levels. Female are tended to be at risk for obesity compare to male. Obesity is one predictors of insulin resistance. High percentage of free fatty acids in the blood leads to lower glucose transport into cells. In the other hand, estrogen levels also delay the mobilization of fat in blood vessels and caused insulin resistance which prohibited the absorption of glucose into the cells Thus, this condition resulted women are more at risk of developing DM. ${ }^{10,11}$

High blood pressure affects the sensitivity of cells towards insulin. Chronic hypertension increases the occurrence of insulin resistance. In the carbohydrate metabolism, insulin is the key component to absorb blood sugar into a cell. However, the insulin resistance cause the body to have less response to the increasing of blood sugar. 1,12

Both groups showed that there were decreasing of blood sugar levels after administering DM drugs and combination of DM with garlic. However, administering garlic with antidiabetic drugs lowering the blood sugar levels in a significant amount compare to only drugs. This evinces that combining DM drugs together with garlic generate a better result of medication. In this study, the deflation on glucose level were still not reach the normal limits. This can be assumed that applying antidiabetic drugs together with garlic only for two weeks has not been effective in reducing blood sugar levels to normal levels.

The results of this study is different from the research by which found out that there is a significant effect of administration of garlic combined with metformin for 12 weeks on the average of blood sugar level with mean is $6.30 \mathrm{mg} / \mathrm{dl}$ after administration of garlic combined with metformin for 12 weeks. $^{13}$ The statistical analysis indicated that the fasting blood sugar levels decreased significantly after 12 weeks treated with metformin supplementation accompanied by garlic consumption compared to before garlic supplementation $(\mathrm{p}<0.001)$ and after 12 weeks of metformin supplementation $(\mathrm{p}<0.05)$. However, the length of the therapy administration should be considered as the associated factors to the study result.

Garlic can improve metabolic syndrome such as hyperglycemia, hypercholesterolemia and hypertension. The ability of garlic in reducing lipid peroxidation is through mechanism of reducing levels of malondialdehyde. This resulting a protection of heart blood vessels from damage due to oxidative stress ${ }^{14}$. In addition, late eating dinner behavior also bring negative side effect on the blood sugar level in diabetic patient. Around $30 \%$ of this study respondents habitually had dinner at night. Bad diet management affects the high levels of blood glucose although they had consumed metformin. ${ }^{15,16}$

\section{CONCLUSION}

The study found that the administration of 3 pieces of garlic combining with antidiabetic drugs for 2 weeks has not been able to reduce blood sugar levels into normal limits. However, this combination found to lowering the blood sugar levels in a significant amount compare to only drugs. The length of the therapy could consider as a significant predictor. In addition, the consumption of garlic must also be followed by lifestyle changes such as diet, exercise and stress management.

\section{ACKNOWLEDGEMENTS}

The authors thank to Director of Publich Health Centre Lumpo, Pesisir Selatan, Indonesia and all of respondents.

\section{Funding: No funding sources}

Conflict of interest: None declared

Ethical approval: The study was approved by the Institutional Ethics Committee

\section{REFERENCES}

1. Brunner DS, Smeltzer LS, Suddarth SC. Brunner and Suddarth's textbook of medical-surgical nursing. $14^{\text {th }}$ edition. Lippincott Williams and Wilkins. 2010.

2. Sinata N, Arifin H. Antidiabetic of Caramunting (Rhodomyrtus tomentosa (Ait.) Hassk) leaf water fraction against blood glucose levels of diabetes mice. J Pharm Clin Sci. 2016;3(1):72-8.

3. Bruton L. Goodman and Gilman. The Pharacological Basis of Therapeutics. 10th ed. McGraw Hill Education. 2007.

4. Majewski M. Allium sativum: facts and myths regarding human health. Rocz Państw Zaki Hig. 2014;65(1):1-8 
5. Buendía HA, González AT, Reyes S, Arroyo OG, García A, Tapia R, et al. Immuno-modulatory effects of the neutraceutical garlic derivative allicin in the progression of diabetic nephropathy. Int $\mathrm{J}$ Mol Sci. 2018;19(10):3107.

6. Suleria HAR, Butt MS, Khalid N, Sultan S. Garlic (Allium sativum): diet based therapy of 21 st century - a review. Asian Pacific J Trop Dis. 2015;5(4):2718 .

7. Bayan L, Koulivand PH, Gorji A. Garlic: a review of potential therapeutic effects. Avicenna J Phytomed. 2014;4(1):1-14.

8. Wang W, Zhang J, Lan X, Wang H. Effect of garlic supplement in the management of type 2 diabetes mellitus (T2DM): a meta-analysis of randomized controlled trials. Food Nutr Res. 2017;61(1)20-7.

9. Putri D. Relationship of obesity and age with the event of diabetes mellitus type II. J Med Saintika. 2017;8(2):17-24.

10. Nuryanti I, Bantas K. Prevalance and risk factors for diabetes mellitus in women adult in Indonesia. 2010.

11. Isnaini $\mathrm{R}$, Ratnasari N. Risk factors influence the incidence of type two diabetes mellitus. J Nursing Midwifery. 2018;14(1):59-68.

12. Parati G, Ochoa G, Salvi JE, Lombardi P, Bilo C. Prognostic value of blood pressure variability and average blood pressure levels in patients with hypertension and diabetes. Diab Care. 2013;36:13-7.

13. Shoshi H, Akter MSJ. Effects of garlic (Allium sativum) on blood glucose level in type 2 diabetes mellitus patients treated with metformin. J Enam Med Coll. 2017;7(3):57-63.

14. Naderi R, Mohaddes G, Mohammadi M, Alihemmati A, Badalzadeh Z. On oxidative stress and histopathology of cardiac tissue in streptozotocin-induced diabetic rats. 2015;102(4):380-90.

15. Dafriani P. The relationship between diet and physical activity against the incidence of diabetes mellitus in internal medicine polyclinic. J Kepara. 2017;13(2)2:87-9.

16. Garber P, Klein A, Bruce E, Sankoh S. Metforminglibenclamide versus metformin plus rosiglitazone in patients with type 2 diabetes inadequately controlled on metformin monotherapy. Diab Obes Metab. 2006;8(2):156-63.

Cite this article as: Dafriani $\mathrm{P}$, Marlinda R, Arman E, Idaman M. Garlic: an alternative in reducing blood glucose on diabetic patients. Int J Community Med Public Health 2020;7:2078-81. 